\title{
Tribal communities and coal in Northeast India: The politics of imposing and resisting mining bans
}

\author{
Duncan McDuie-Ra ${ }^{\mathrm{a}, *}$, Dolly Kikon ${ }^{\mathrm{b}}$ \\ ${ }^{a}$ UNSW, Australia \\ ${ }^{\mathrm{b}}$ University of Melbourne, Australia
}

\section{H I G H L I G H T S}

- Tribal communities initiate and manage coal mining in Nagaland and Meghalaya.

- Laws banning coal extraction have been challenged and resisted by local communities.

- The right to extract coal is tied to protecting tribal land rights.

- Tribal autonomy in coal policy is progressive, yet enables capture by local elites.

- Where there has been regulation of coal mining it has come from unexpected sources.

\section{A R T I C L E I N F O}

\section{Article history:}

Received 29 November 2015

Received in revised form

4 May 2016

Accepted 11 May 2016

\section{Keywords:}

Coal bans

Northeast India

Tribal communities

\begin{abstract}
A B S T R A C T
Bans on coal mining have been implemented in two tribal majority states in India's north-east frontier; Nagaland and Meghalaya. In Nagaland the state government imposed the ban in an attempt to capture control of coal extraction and trade, while in Meghalaya India's National Green Commission imposed the ban over concern for the environment and labour conditions. In both cases local communities have opposed the bans, and in some areas resumed mining under the authority of tribal councils and powerful civil society actors. In this paper we explore the politics of coal extraction that resulted in these bans and the response of communities and authorities. In doing so we made three main arguments that contribute to understanding of coal and communities in frontier regions where state control is partial and the legacy of armed conflict is powerful. First, in both locations the majority of the coal mining activity has been initiated and managed by members of tribal communities rather than profit-driven outsiders. Second, in contrast to other contexts in India (notably Orissa and Jharkhand) where large state or private enterprises seek to modify the law to enable coal extraction, in Nagaland and Meghalaya it has been communities that resent and challenge state and national laws being applied to their lands. Third, the right to extract coal is connected to the right of tribal communities to determine what happens on their lands.
\end{abstract}

(c) 2016 Elsevier Ltd. All rights reserved.

\section{Introduction}

This paper explores the relationships between coal and communities in Northeast India: a political and economic frontier sharing borders with Bangladesh, Bhutan, China, Myanmar, and Nepal. We focus on the experiences of tribal communities engaged in coal mining activities in Nagaland and Meghalaya, two federal states with tribal majority populations with special constitutional provisions. Despite being majorities in their own territorial units, these communities are national minorities and have been engaged

\footnotetext{
* Corresponding author.

E-mail addresses: d.mcduie@unsw.edu.au (D. McDuie-Ra), dollykikon@gmail.com (D. Kikon).
}

in resistance to the Indian state for over six decades-especially in Nagaland. The politics of coal in the frontier of Northeast India illustrate three main dynamics that complicate assumptions about the relationships between coal and communities. First, in both locations the majority of the coal mining activity has been initiated and managed by members of tribal communities. Rather than profit-driven outsiders, the initiators of extraction are predominantly local and are members of communities often cast as victims of resource extraction. Second, laws banning coal extraction have been challenged and resisted by local communities. In contrast to other contexts where large state or private enterprises seek to modify the law-and often break it-to enable coal extraction, in this case it is local actors who resent national and state laws being applied to their lands and jeopardizing their livelihoods. Third, the right to extract coal is closely linked with the 
right of tribal communities to determine what happens on their lands. For communities seeking various forms of territorial autonomy, control over resource extraction is at the forefront of political action, regardless of national and state energy policy and priorities. These dynamics have implications for our understanding of the ways tribal communities are understood in relation to coal, the relationship between territorial politics and coal extraction at the sub-national level, and the efficacy of national level laws in frontier regions.

\section{Methodology}

Research for this paper was conducted through ethnographic fieldwork by the authors in the coal areas of Nagaland (20072011) and Meghalaya (2005-2008) as part of two separate but related projects on tribal communities and extractive resources. In each location the authors carried out in-depth interviews and observations to establish the dynamics of local resource politics. Coal was an integral part of these politics in both locations. In order to best capture the phenomenal changes of the last 2 years, we consulted updated government data, national and state laws, and secondary literature-much of which appeared in the vernacular press. We situate these two cases in the broader context of tribal and indigenous communities being forced to protect their land and mineral resources against profit-driven outsiderswhether state or corporate (see Ballard and Banks, 2003; Kirsch, 2014; Li, 2000). In many of these instances, especially in India, tribal communities have been completely marginalized from decisions over land and resource extraction, have been poorly protected by the law, and have often experienced violence in removal and resettlement (Baviskar, 1997; Ghosh, 2006; Kennedy and King, 2013; Oskarsson, 2013; Padel and Das, 2010; Routledge, 2003; Suykens, 2009). As such we are driven by Dove's (2006, 191) proposition to explore the contradictions, collaborations, and complicity "inherent in the coevolution of science, society, and environment". We position the experience of tribal communities in Nagaland and Meghalaya in contrast to these experiences in order to unearth the far more complex and seemingly counterintuitive politics of land and resources in territories where protective land regimes hold firm but where the structural power of coal distorts these regimes in dramatic, and uneven, fashion.

\section{The coal frontier in India}

Nagaland and Meghalaya are federal states in Northeast India. (Fig. 1) Both states are classified as 'special category states' and depend on finance from Indian Government in Delhi for their annual budget transferred directly (as much as $89 \%$ ) and also depend upon grants, loans and other schemes coordinated by the Ministry for Development of the North East Region and the North East Council. Funds released to special category states are $90 \%$ grants and $10 \%$ loans payable over 20 years-very attractive terms for local governments. In the last decade the states of the region have been under pressure to raise more revenue and attract investment. Energy resources including coal, gas, uranium and hydropower are targeted for investment under a number of assisted schemes at the national level, such as the flagship North East Vision 2020 policy framework released in 2008, the North East Industrial Investment Promotion Policy 2007 offering generous concessions for investors, and in the various state investment and industrialisation policies (McDuie-Ra, 2009; 2016). Vision 2020 posits that to achieve peace and alleviate poverty in the region a 'paradigm shift in development strategy' is needed, centred on harnessing the region's mineral resources-coal, gas and petroleum reserves, as well as hydro-power potential, and creating an hospitable climate for investment, border trade, and public investment in infrastructure (MoDONER, 2008, 18-21).

For many communities in the frontier, coal is the most accessible and controllable resource, particularly given the methods of extraction common at the local level. Of primary importance in coal extraction at the national level is the Ministry of Coal, separated from the Ministry of Power, Coal, and Non-Conventional Energy Sources in 1992 and embroiled in scandals ever since, including the infamous 'coalgate' wherein the Ministry was accused of corruption in the allocation of coal blocks (Miklian and Carney, 2013). The Coal Bearing Areas (Acquisition and Development) Act, 1957 enables the Indian Government to acquire land for coal extraction through a series of stages, and its implementation has been the source of the recent controversy. In response, the Coal Mines (Special Provisions) Act was passed in 2015 opening coal mining private investors from India and abroad (Ministry of Law and Justice (India), 2015; Government of India, 2015). This has opened India's domestic coal market to exports from places like Australia.

In a 2015 Australian Government Report, the Office of the Chief Economist noted: "Although prices, coal quality and investment have thus far limited growth in Australia's thermal coal exports to India, these barriers are now starting fall" (Office of the Chief Economist, 2015, 82). Australia's exports of metallurgical coal (also known as coking coal) have tripled between 2001 and 2014, while thermal coal remains expensive for Indian buyers when compared to other sources, notably Indonesia, exemplifying Anna Tsing's famous description of the transformation from "coal-the-diggable, coal-the-sortable, coal-the-transportable, until it eventually becomes coal-the-burnable...[and] rubs up against other participants in the chain: unhappy villagers, conveyor belts, contracts" (2005: 51). The Coal Mines Act has implications for coal mining in the Northeast frontier as the supply of imported coking coal alters demand for similar quality coal from places like Meghalaya and Nagaland, particularly given the difficulties in extracting coal in the context of the bans discussed below. At the same time the Indian Government has urged an increase in domestic coal production, part of a series of reforms including easing barriers to extraction such as environmental clearances and land acquisition (Bedi and Tillin, 2015; Ruparelia, 2015). As of early 2016 oversupply was being reported and stock levels at power stations had reached a record high, making the future for metallurgical imports uncertain (Burton, 2016). However, the coal scenario in Nagaland and Meghalaya is vastly different to the national scenario given that national and state governments must content with constitutional provisions that guarantee tribal communities control over land.

Tribals constitute $86.5 \%$ of the population of Nagaland and $86.1 \%$ of the population in Meghalaya-split among the Khasi and Garo communities (Census of India, 2013). The terms 'tribal' and 'tribe' denote membership of the Scheduled Tribe category in the Indian Constitution which grants designated communities various constitutional guarantees ranging from territorial autonomy, federal statehood, reserved posts in state institutions and assemblies, and recognises the authority of customary courts, councils, and law; all vital in the politics of coal. In addition, politicians and leaders with strong tribal and clan solidarities head the formal political institutions in these hills states as members of regional and national political parties. In Nagaland and Meghalaya special constitutional provisions relating to land ownership and resource management are a powerful counter to national level laws promoting coal mining, and, conversely, seeking to ban mining in these states in recent years following an apparent 'green turn' at the national level. 


\subsection{Extraction and militarization}

The history of the Northeast is bound up in colonial resource extraction and militarization (Baruah, 2001; Kar, 2009; Kikon, 2014). Extractive economic regimes like tea and oil set up by the British administration transformed the landscape of this frontier region from the mid-19th Century through the clearing of forests, the importing of labour, and the partitioning of land into various categories of use and habitation (Saikia, 2008; Sharma, 2009). Oil was discovered in upper Assam near Moran, Digboi, and Makum and the British Burmah Oil Company was given a ninety-nine year lease on the oil fields from 1889 (Brown, 2009; ONGC, 2009). As several authors have noted, the colonial officials were optimistic about the coal potential in erstwhile Assam by the mid-19th Century, particularly as an alternative to the supply from Bengal (Saikia, 2011). Coal was discovered in upper Assam at Makum in 1865 and at Ledo in 1882, which accelerated the development of the tea industry as coal was used to fuel the tea processing factories (Saikia, 2005: 197-8). A railway was built between the oil fields, coalmines, and tea plantations in Upper Assam and the Brahmaputra River in 1885. During the same period, the colonial authorities sought to control the opium crops in Assam by expanding the cultivation of the crop and introducing manufactured opium into the markets.

Displacement and violence characterised this periods along with the emergence of a powerful elite involved with these lucrative industries (Iqbal, 2015; Liu, 2010; Saikia, 2011; Sharma, 2006). Extractive industries were presided over by Europeans with a hierarchy of administrators, clerks, traders and migrant labourers underneath, marginalising the local populations. These arrangements had different impacts in territories that make up present day Meghalaya and Nagaland. In Nagaland, the British administration started coal mining in 1907. The first coal mines started in the Konyak areas (one of the Naga tribes) along the foothill border of present day federal states of Assam and Nagaland. In order to carry the coal to the Brahmaputra valley of Assam, a coal loading station was developed at Naginimora. This brought the authorities to the foothills and in some sense helped to define where the hills and plains, where the tribal and non-tribal habitus, began and ended. However extraction in the Khasi Hills was more complex and remained subject to indigenous control of land and minerals despite claims of the Assam Railways and Trading Company to coal fields in the hills (Ludden, 2012: 21). As Arup Saikia notes,

Unlike the coalfields in eastern Assam, rights over the coalfields in the Khasi Hills remained mostly within the community institutions. The administration negotiated directly with the community chiefs, and petty trade grew around the coalfields.

The method and mode of extraction essentially remained dependent on the capacity of the Khasi villagers (Saikia, 2014, 71).

Transport out of the hills was also difficult making the costs of investing high, and when coupled with the prospects of resistance from locals, less attractive than other sources in the frontier (see May, 2014).

Since 1947, the northeast frontier has witnessed a series of low intensity armed conflicts between the Indian Government and armed groups demanding homelands of varying levels of autonomy (Baruah, 2005; Barbora, 2008). The desire for control of land, resources, and settlement in tribal majority areas is at the forefront of these struggles, reflecting histories of violence, extraction, and state-making in forests, frontiers, and coastlines throughout Asia (Li, 2002; Kelly and Peluso, 2015; Ribot and Peluso, 2003; Vandergeest, 2003). In light of this history, issues of governance and regulations of land and people, particularly in terms of extractive economic regimes are an integral factor in the region's politics, economy, and social stability. In Nagaland and Meghalaya coal mining activities are subject to politics reflecting this history.

\section{Coal in Nagaland}

Nagaland is a federal state in India sharing a border with Myanmar and with the federal states Assam, Arunachal Pradesh and Manipur with a population of around 2.2 million. The present boundaries of Nagaland were created in 1963 and remain heavily contested. The Indo-Naga ceasefire in 1997 was a watershed moment signalling the end of fighting between Naga insurgent groups and the Indian Government. However, it simultaneously led to increase in conflicts between different Naga armed factions seeking legitimacy and authority over people and resources. The external conflict turned internal. Following the ceasefire stake holders-including various factions of Naga insurgent groups, representatives to the Naga tribal councils, student bodies, cultural associations and the state legislative assembly-have vied for the right to represent the Naga past and their future; a future bound up in coal.

Nagaland has moderate coal reserves of approximately 316.41 million tonnes and mining takes place across the districts of Mokokchung, Wokha, Dimapur, Longleng, Mon, and Peren (Fig. 2) (Government of Nagaland, 2009; 2014a, 2014b). Permission to mine is granted through patronage networks of powerful actors ranging from Naga politicians, non-Naga contractors, insurgent groups, and local landowners. Mining takes place in small freehold mines using open pits and small tunnels and most labour comes from surrounding areas.

Over the last decade the scale of coal mining, trading, and investments in infrastructure to extract coal drew the attention of the Nagaland Government. Concerns about environmental degradation such as deforestation, pollution of village streams and rivers, and contamination of agricultural lands began to surface. State officials argued that coal mining should be regulated, organized, and brought under the ambit of the state government. These debates brought Article 371 (A) of the Constitution of India into play.

\subsection{Article 371 (A) and Nagaland coal policy}

Article 371 (A) of the Constitution of India guarantees special protection for Naga people living in Nagaland in relation to land ownership and resources. This is a stronger guarantee of rights to minerals beneath the soil (deeper than six feet) that the provisions of the Sixth Schedule and various federal state acts (including Meghalaya) that mostly protect the transfer of land for agricultural purposes. The provision has three clauses, however the interpretation of clause (1) sub section (A) is at the centre of the conflict over coal. Sub section (A) point (iv) states that no Act of Parliament 'in respect of the 'ownership and transfer of land and its resources, shall apply to the State of Nagaland unless the Legislative Assembly of Nagaland by a resolution so decides' (Bakshi, 2014). According to this provision, Naga people-here represented by the state legislature-have the power to decide what kinds of activities take place on, and underneath, their lands. Article 371 (A) is paramount in coal politics. However the issue at hand is not whether coal should be mined in the first place-in other words Article $371(\mathrm{~A})$ is not invoked in opposition to coal mining-rather the issue is precisely who among the circuitous network of authority and control between individuals, kin groups, village councils, and the state government authorities has the right to extract coal and trade it.

The major contention is the overlapping jurisdiction of traditional customary law and the state government bodies like the 
Directorate of Geology and Mining. This overlapping jurisdiction is visible in the manner permissions for coal-mining activities have been granted in Nagaland since 2006. The Nagaland Coal Policy of 2006 empowered the Directorate of Geology and Mining to control coal mining through prospecting and extraction licences and leases. However, tribal councils deliberate on everyday matters of coal mining as part of their role arbitrating land and natural resource matters as per customary law, bypassing state policies.

In 2011, Chief Minister of Nagaland Neiphiu Rio issued a press statement reinterpreting Article 371 (A) in the light of the debates around resource extraction, including coal. Neiphiu highlighted how Nagaland was blessed with huge deposits of mineral resources (Morung Express, 2011). If these mineral resources were 'exploited and utilized', both the state of Nagaland and the Naga people would enjoy economic prosperity. He added that Article 371 (A) was a special constitutional safeguard for the preservation and protection of the 'Naga way of life'. He acknowledged the ownership of land and its resources by the people of Nagaland, but stated that it was up to the state government 'to frame laws and regulations and to work out the modalities for exploration and exploitation of our mineral resources'.

In 2014, the Nagaland Government amended the 2006 Coal Policy banning coal-mining activities with effect from the month of October. The state ban on coal mining activities would be imposed until the state set up its own structures comprising of the Nagaland Coal Controlling and Trading System and Integrated Coal Depots. According to the 2014 amendment, the state government would directly broker coal deals with private companies and agencies and declare the contracts and activities of local coal traders and landowners as null and void. Further, other than the designated government coal depots, all other private coal depots in Nagaland would be declared as illegal. In a dramatic grab for power over resources, the state government used their interpretation of Article 371 (A) to subsume control of coal mining across Nagaland. Perhaps most significantly for a population worn down by decades of violence, the 2014 amendment states that the state government will impose these changes by deploying security forces to the coal mining areas, coal depots, and increasing the number of check gates to enforce the new rules and regulations. In short, the coal mining areas and villages were to become militarized to prevent communities and individuals mining without approval.

\subsection{Resisting the coal ban}

Both the 2006 and 2014 coal policies are very unpopular in coal mining areas of Nagaland. Some of the most vocal protests against the ban on coal mining have come from the foothill villages in Mokokchung and Mon districts. During fieldwork in these villages between 2007 and 2011, residents shared their anxieties about the state's actions to ban coalmining activities. Lima, a female coal trader in a foothill village, described why residents oppose the ban:

I told the minister, you have come to this village for this first time and then order us to stop coal mining...you are coming to stop what is being produced from our own farm - the coal is coming out from our own land. It is not your land, it is our land and we will not allow you to ban it.

Such exchanges between residents in coal mining villages and the state government are typical.

Militarization, violence and poverty have produced an uneven and dysfunctional economy-especially in rural areas-characterised by poor employment prospects and state neglect (Kikon, 2010). In Mon, the absence of basic amenities and medical and education facilities is conspicuous. Many of the villages are inaccessible due to absence of roads and bridges. Under such circumstances, villagers are migrating from remote villages to coal areas in Mon and other districts. Coal extraction in Naga villages is risky. At the village level there are reports of deaths inside the open cast coalmines but these accidents are often unreported more widely lest they trigger state intervention. Poor villagers from the local area make up the majority of the workforce, unlike the situation in Meghalaya discussed below where the workforce is mostly migrants. Some of them own small patches of farmland that are not sufficient to feed the household, while others are landless (Kikon, 2014). In Mon district, one of the largest coal mining areas in Nagaland, several families have stopped growing food and converted their fields into coal mines or potential sites to explore for coal. Often this means leasing out their small cultivable lands to private companies who have the financial means to start exploratory works. Thus thousands of locals are dependent on the coal trade for their livelihood. From their perspective the ban on coal mining is tantamount to losing control of mineral resources on their community lands.

However, resistance to the coal ban has not been uniform. In February 2014, the Konyak Students Union-a powerful civil society actor in the Mon District-welcomed the initiative. Reiterating the position of the Nagaland Government, the Konyak Students Union decried the environmental damage that private coal traders have caused to the village lands (Shillong Times, 2014a). However in October the same year, the Konyak Students Union reversed their stance declared that the Konyak villages in Mon District would continue mining coal. This decision, according to the press statement, was jointly taken together with the landowners, traders, and village councils. Villagers in Mon stated that they would continue the coal mining activities following a 'legal and systemic approach' (Eastern Mirror, 2014). Accordingly, the traditional village councils declared they would resume providing No Objection Certificates-effectively granting permission to mine - provided applicants provide proper verification.

The turn of events here is insightful. The ban was upheld in Mon for 8 months. Yet after pressure from powerful non-state actors including the Konyak Students Union and an alliance of landowners, traders, and traditional councils decided to resume coal mining. The extraction of coal depends not only on the existence of energy policy at the national and/or state levels but on the way powerful local actors interpret legal and illegal mining operations and core constitutional mechanisms. The matter at hand is not solely about extractive economies like coal, but a larger issue about collective ownership of land and the control of resources.

\section{Coal in Meghalaya}

Meghalaya is a small state bordering Bangladesh and the Indian state of Assam with a population of around two million people. It was created in 1972 out of the larger state of Assam to provide a 'homeland' to the hill-dwelling Scheduled Tribes, though, by the time it came into existence, it was limited to Khasi and Garo communities as other Scheduled Tribes opted to carve out their own states (Mathur, 1982). The Meghalaya Transfer of Land (Regulation) Act, 1971 prevents land being transferred to non-tribal people, while the Sixth Schedule of the Indian Constitution (as in most other tribal areas in the Northeast) gives authority in matters of land to traditional institutions of governance at the district and village level (Nongbri, 1999). However, under the Sixth Schedule the Indian state can still make claims on minerals beneath the surface (more than six feet). The Meghalaya Land Transfer Act does not prevent this either, nor does an amendments to the Act passed 
in 2012 (Government of Meghalaya, 1971; 2012). As will be seen in the context of the ban, the Indian Government believes it has the right to prevent-in this case-tribal communities from mining under the Sixth Schedule. In comparison to Nagaland, Meghalaya has not been engaged in long-running armed insurgency against the Indian state, despite sporadic outbreaks of anti-India violence (Haokip, 2014; Karlsson, 2011).

Tensions and occasional violence between tribal communities is a feature of life in different parts of the state at different periods. Violence against non-tribal migrants (and non-tribal residents born in the state) has been a feature of political life since the late 1970s. The long land border with Bangladesh is also a source of anxiety for communities concerned with land and the cultural resilience of relatively small Khasi and Garo communities. The fencing of the entire India-Bangladesh border was supported by various groups in Meghalaya but opposed by others-suggesting a complex and nuanced politics around land, mobility, and access to markets (McDuie-Ra, 2014).

\subsection{Coal boom and consequences}

Coal mining has been taking place in the erstwhile Khasi Hills (now the eastern part of Meghalaya) since the 1840s, but production only reached significant levels in the 1980s and has been accelerating ever since (Vakkayil and Canato, 2015).

The Meghalaya Government estimates present day coal reserves of 576.48 million tonnes, though only 133.13 million tonnes are classified as 'proved' (Fig. 3). The coal boom in Meghalaya has seen annual production rise from 39,000 tonnes in 1979 to 5 million tonnes in 2014 (Government of Meghalaya, 2015 n.d). The majority is sub-bituminous with medium to high sulphur content.

Most mines are small but widespread. Known as 'rat-hole' mines, pits are dug down from the surface to reach the coal and tunnels are dug in from the sides. These mines are spread throughout Meghalaya, but are most heavily concentrated in the Jaintia Hills-home of the notorious Lad Rymbai mining area (often featured in media stories condemning coal mining), the Khatar Shnong area in the East Khasi Hills, around Baghamara in the South Garo Hills, and the area around Nongjri in the West Khasi Hills. As the mining takes place on Sixth Schedule land, the majority of coalmine owners are tribals, and the landowners are free to grant leases under their own terms and conditions for coal mining (McDuie-Ra, 2007).

The boom has had a major impact on land, livelihoods, and wealth inequalities. Families who own land where coal has been mined and those able to use tribal council to claim title or lease on land in these coal rich areas have become very wealthy, exacerbating the divisions between rich and poor, between those who own land and those who do not. Talk of a 'coal mafia' in Meghalaya is rife, and usually refers to the nexus of politicians, armed militant groups, leaders in tribal councils, and financiers who profit from coal and bend the various layers of the law to accommodate mining. The boom on coal profits has encouraged armed extortion in the coal areas and 'taxing' of coal being transported through the state and into neighbouring states. As Bengt Karlsson notes (2011, 208-14) coal mining in Meghalaya operates as a 'shadow' economy, wherein tribal councils, traders associations, armed extortionists and insurgents, various tiers of government, border security forces (in the case of exports to Bangladesh) and even weigh bridge and toll gate operators have long operated with legal impunity-that is, until the 2014 ban.

The landscape of the mining areas has been transformed. Palatial houses stand next to corrugated iron shacks of mine workers. The land along the hilltops is like a lunar landscape; rubble-strewn holes and abandoned wooden trolleys mark the entrances to the old mines. Many of the mines are no longer economically viable as the coal is now up to two kilometres deep. In steep mining areas like Khatar Shnong landslides have increased as the mines have been dug deeper into the hillsides, soil erosion has increased as the structure of the soil is undermined by the clearance of vegetation and the number of mines being dug, piles of coal dust and other debris from mining operations are carried by wind and rain into fields damaging soil and crops, and much of the land that has been mined and abandoned is marked by craters and is thus unable to be cultivated. Mining has a major impact on rivers and watercourses. Despite high monsoonal rainfall in Meghalaya, water retention is difficult due to the steep topography and denuded hills. The watercourses that flow through the valleys are vital for the supply of water to villages for cooking, washing, and farming, but coal mining has polluted many of the main watercourses running through rural areas. Thus it is important to point out that the environmental consequences of coal mining have been extremely negative.

For most of the boom period, these impacts rarely initiated political action, with the exception of moral anxieties about prostitution and drug use in mining areas (McDuie-Ra, 2007). As in Nagaland the nexus between those enriched by mining, state government officials, and holders of traditional authority meant opposition to coal mining was minimal (see Karlsson, 2011). However things began to change in the late 2000s and early 2010s. Concern from NGOs over labour practices in the mines, especially child labour-which was reported through international media outlets (see Miller, 2015), and from tribal organisations over the growing presence of non-tribal migrants from outside Meghalaya and even outside India (especially Bangladesh and Nepal) in the mining areas and the frontier settlements surrounding them, began to bring more internal scrutiny to coal mining (NESRC, 2013).

As in Nagaland, the conditions in the mines are dangerous. During fieldwork in the mining areas the conditions for labourers present a further dimension to the social impacts of coal, though one predominantly affecting migrants with few prospects of political participation or representation. The mining is done in low and narrow shafts often kilometres below the surface. Miners suffer from the effects of poor ventilation, silicosis from coal dust inhalation, all kinds of bodily complaints, and the risk of mine collapse. Most of those working on the coal mines live in shantytowns or camps at the mine sites with no sanitation, poor shelters that cannot sustain the volume of rain in the wet season, and are captive to merchants selling food and water-especially at the remote sites.

Migrant labour was tolerated in the early years of the boom, yet from the late 2000s as more and more migrants arrived in the Meghalaya coal fields-driven by a range of factors as diverse as the end of civil conflict in Nepal and the need for former fighters to find livelihoods, the Global Financial Crisis reducing remittances from family members working abroad, political turmoil in Bangladesh, and the acceleration of conflicts in nearby parts of the Northeast such as the Bodo areas of Assam-local opposition grew. The main focus of opposition has been on Nepali-speaking migrant miners (some from Nepal and some from other parts of India) who are accused of taking jobs from locals in the mines and threatening tribal land and culture (Wagle, 2010); a charge that has a long history in the expulsion of Nepalis from Meghalaya in the 1970s and 1980s. Opposition to Nepali-speaking migrants culminated in 2010 in a violent episode at Lampi (Langpih) village-a disputed area on the border between Meghalaya and neighbouring Assam, where Nepali-speaking migrants, many of whom are mine-workers, are accused of settling and thus boosting Assam's claim to the territory. The incident began with the assault of a Nepali-speaker and resulted in the shooting of four Khasi (tribal) villages by the Assam State Police and the formation of a high-level government inquiry (The Justice PC Phukan Inquiry Commission). While 
seemingly unrelated to coal mining, the Lampi incident heighted general opposition to Nepali-speakers settling in Meghalaya. In 20138 migrant coal workers were killed in the South Garo Hills, promoting several thousand to flee the area (The Hindu, 2013).

Estimates on the number of migrant workers in the coal mining areas of Meghalaya range from 150,000 to 35,000 (Madhavan, 2005; The Hindu, 2013). Accurate numbers are very difficult to obtain given some migrants come from outside India, some from within, and movement between Nepal and India is not monitored under the 1950 India-Nepal Friendship Treaty. Furthermore mine owner and operators seek to disguise the number of migrant labourers fearing crackdowns by ethno-nationalist groups and antimigration organisations. However not all labour in the mining areas comes from migrants. In the mines around Nongjri in the West Khasi Hills for example, Nepalis, Bodos (a tribal community from Assam), Bengalis, and a large number of tribals from the Ri Bhoi district in Meghalaya live and work in the mine site. Landless labourers from nearby villages also work in the mines from time to time, but many cultivate crops as well. Yet opposition to coal mining within Meghalaya comes not from the environmental impacts but from concern over number of migrant workers and the perceived threat they pose to livelihoods, territory, and culture of tribal communities.

\subsection{Coal ban}

If opposition to coal within Meghalaya has been focused on the labour force, opposition from outside the state was driven by environmental concerns. In April 2014 the National Green Tribunal (NGT), established under a 2010 Act of Parliament to fast track 'environmental justice' issues outside the Code of Civil Procedure (National Green Tribunal, 2015; NGT, n.d.), ordered the Meghalaya Government to ban illegal 'rat-hole' coal mining and illegal transportation of mined coal in the state. The ban was heavily influenced by a report by two local academics outlining the environmental impacts of 'rat-hole' mining (Swer and Singh, 2004) and petitions submitted by a number of student unions from adjacent territories in Assam through which coal is transported and has polluted watercourses and landscapes more generally. The interim ban was upheld in early 2015. The police have acted on behalf of the NGT to monitor mine activity and the NGT has even made demands on the Meghalaya Government to reveal the identities of deviant mine owners (Shillong Times, 2015a, 2015b; 2016a; 2016b).

The Meghalaya Government has opposed the coal ban appealing to the NGT to lift it citing the massive losses of revenue and the impact on livelihoods. The Chief Minister of Meghalaya Mukul Sangma estimated losses of 600 crore rupees (US\$92 million). Sangma's claim is difficult to support with data given that the ban has not yet been in place for a full financial year (April to March), making conventional indicators limited in demonstrating a slow down in either production of exports. However, there has certainly been anxiety over the ban in locations reliant on Meghalaya coal, especially Bangladesh. Exports to Bangladesh from Meghalaya are estimated at between 1.6 and 2.1 million tonnes annually, $80 \%$ of which is believed to power brick kilns (Islam, 2014). However, given the volume of coal illegally traded and transported, such statistics can be limited in their value. Nonetheless, a series of meetings between local politicians from both sides of the border have taken place and pressure has been applied to lift the ban. The NGT allowed exports to Bangladesh for a fourmonth period in 2015, but only already extracted coal was permissible for transport (Anik, 2015).

A range of political parties and civil society organisations have also opposed the ban, including the recently formed Movement for Indigenous Peoples' Rights and Livelihood-Meghalaya (MIPRL) which invoked the Sixth Schedule in their opposition to the ban. In particular they, and others, cite Paragraph $12 \mathrm{~A}$ which protects tribal rights over land and land use (Shillong Times, 2014b). Coal smuggling is allegedly rife following the ban and the local media carries regular reports of coal smugglers being apprehended by various security forces, particularly when attempting to smuggle coal into Bangladesh-the primary market for Meghalaya coal (Khan, 2014).

Unlike in Nagaland where the state government imposed the ban in an attempt to exert control over coal mining, the Meghalaya Government is in a difficult position of having a ban imposed from a national body and having to contend with the fallout locally. Coal is woven into the political power structure in the state that includes state and non-state actors. As one journalist put it when reporting on the impact of the ban, 'every aspect of life in Meghalaya, including politics, is linked to the coal trade' (Siddiqi, 2015). Indeed the Chief Minister of Meghalaya has declared several landholdings that contain coalmines and his children also own mines in parts of the state (Siddiqi, 2015). There is an additional issue at play; the Meghalaya Government has passed its own mining laws under The Meghalaya Mines and Mineral Policy (2012) which adhere to the principle of customary land use and tribal control of land in the state regardless of whether they contravene elements of national coal laws and policy. The Meghalaya policy does not discuss rat-hole mining, framed as a 'traditional' form of mining that is beyond state intervention, stating in clause 7.6 that 'small and traditional system of mining by local people in their own land shall not be unnecessarily disturbed' (Government of Meghalaya, 2012: 392). The NGT has challenged the Meghalaya Mines and Mineral Policy and requested a revised version by late 2015 (Shillong Times, 2015a, 2015b). Like the Nagaland Government the Meghalaya Government seeks to control coal mining in the state, yet the Meghalaya Government wants to avoid tensions with tribal councils. It is the restrictions imposed by a national body preventing the Meghalaya Government taking control of coal mining, opposition 'from above' as it were, rather than opposition from below as in Nagaland.

Common to both cases is the right of tribal communities to control land through customary measures is considered inviolable in the formation of policy and laws around coal and other mining, regardless of the kinds of practices and impacts mining has on communities and the ways in which intra-tribal differences in wealth, power, and influence shape the ways energy policy is formulated, enacted, and navigated.

\section{Conclusion}

Nagaland and Meghalaya present two complex cases of relationships between coal and communities in border regions of Asia. There are key differences between the cases. In Nagaland the desire for absolute sovereignty shapes and is shaped by the politics of land and coal as does the unique genesis and status of Article 371(A).

In Meghalaya the desire for control over land and the right to continue mining coal is subject to a different legal framework wherein the state can claim minerals beneath the soil, while communities use the argument about control of land to continue mining. In both cases the fight for tribal control over land has been hard-fought, and in the case of Nagaland in particular, punctuated by violence, trauma and loss.

Coal mining exacerbates the tensions over who has the right to regulate and govern the ways land in used; which in turn become proxy debates for who has the right to represent tribal communities. In both cases coal mining has been initiated and managed by tribal communities rather than profit-driven outsiders intent on exploiting indigenous lands. Indeed outsider authorities have had 
more influence on regulating and banning coal mining than encouraging it, especially in Meghalaya.

Yet in both cases elite control-alongside the creation of a 'new' coal elite-from within tribal communities is a significant feature of indigenous control of mineral resources and land. Bans on coal mining and transport-in the case of Nagaland initiated by the state government and in the case of Meghalaya by a national level bodyhave been challenged and resisted in both locations on the grounds of preserving tribal autonomy and the resources underneath it Despite the Northeast borderland being imagined as a storehouse of energy and resource wealth, national mining and energy policies are fervently contested and disregarded on the ground, while state policies seek to reinforce local control-though the beneficiaries of that control varies in each case. Research on coal and communitiesespecially when involving indigenous, tribal, and other ethnic minority groups - often narrates a battle between big capital-whether state or private-and small communities intent on environmental preservation. In both Nagaland and Meghalaya tribal communities and their elected and non-elected representatives-many of who benefit directly from coal profits or are beholden to those who do, defend coal mining and subvert bans. While this in itself is an important issue to contend with in research on coal and communities, care must also be taken to identify the ways coal is bound up in larger question of territory, identity, and representation.

Furthermore, research seeking out the voices of those negatively impacted by coal mining and their agency—or lack of it—is necessary in discovering the fissures within tribal communities exacerbated by coal mining. As both cases demonstrate, coal empowers existing elites in new ways while also bringing other actors-armed groups, traders associations, local politicians, tribal councils, into the nexus.

From a policy perspective the informal exploitation of coal, under tribal authority, has created a 'new coal elite', a bloc empowered by the local and national state's tribal provisions. This coal elite presides over an impoverished (often migrant) labour force, along with increasingly degraded lands and polluted waterways. The imposition of coal bans from the national level transforms this socio-environmental issue into an issue of cultural autonomy, which in the cases above has backfired, and coal has become mired in an increasingly complex battle over intra-tribal resource control. The national level policy of a ban could be rethought, and autonomy for local communities in coal areas given safeguards to ensure those bearing the costs of the coal boom, especially downstream, and the workers in the mines, are empowered and protected rather than simply punished.

\section{Acknowledgement}

The authors would like to thank Jon Marshall, James Goodman, and the anonymous reviewers from Energy Policy for their feedback on earlier versions of this paper. Dolly Kikon's research on the

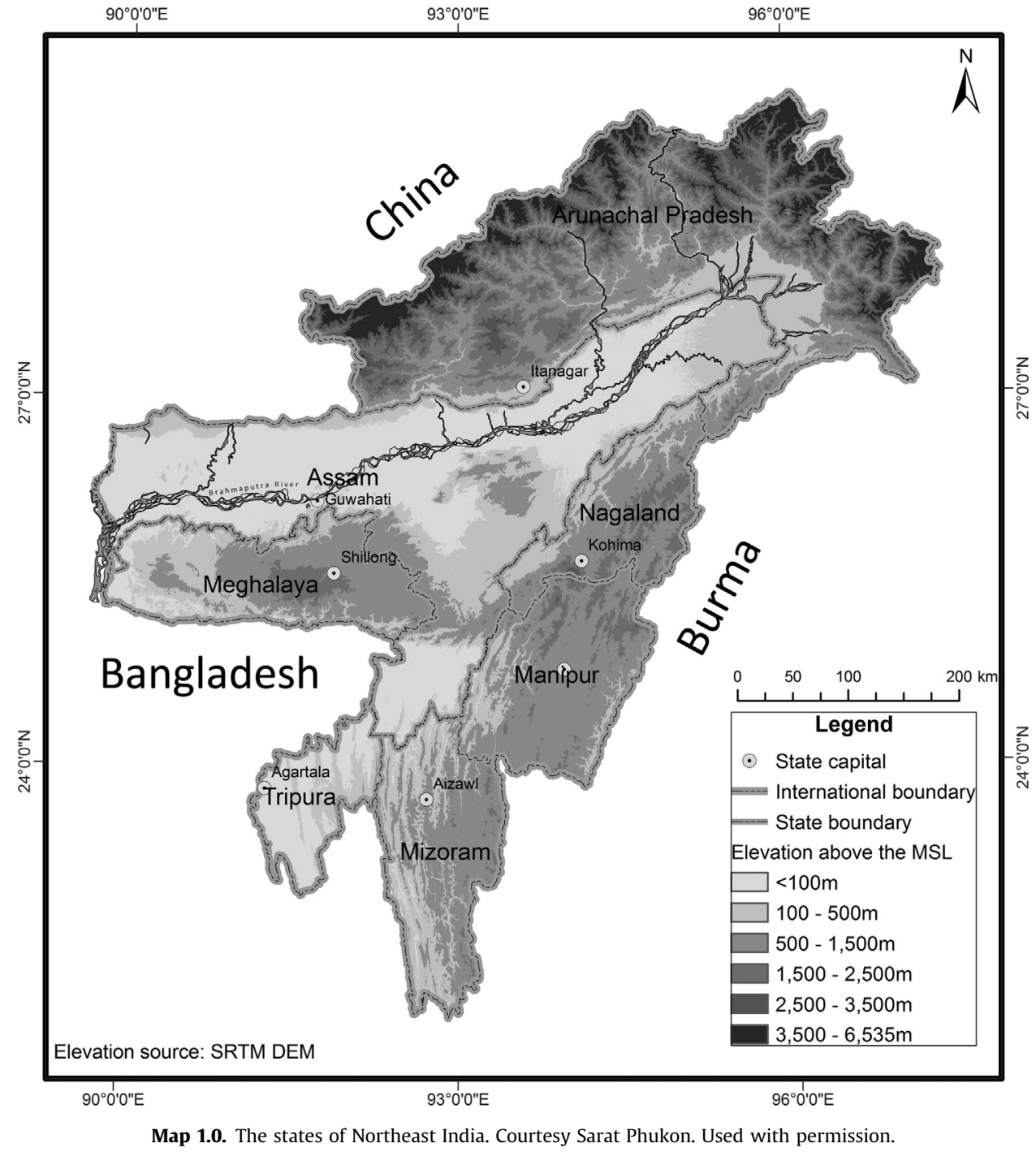




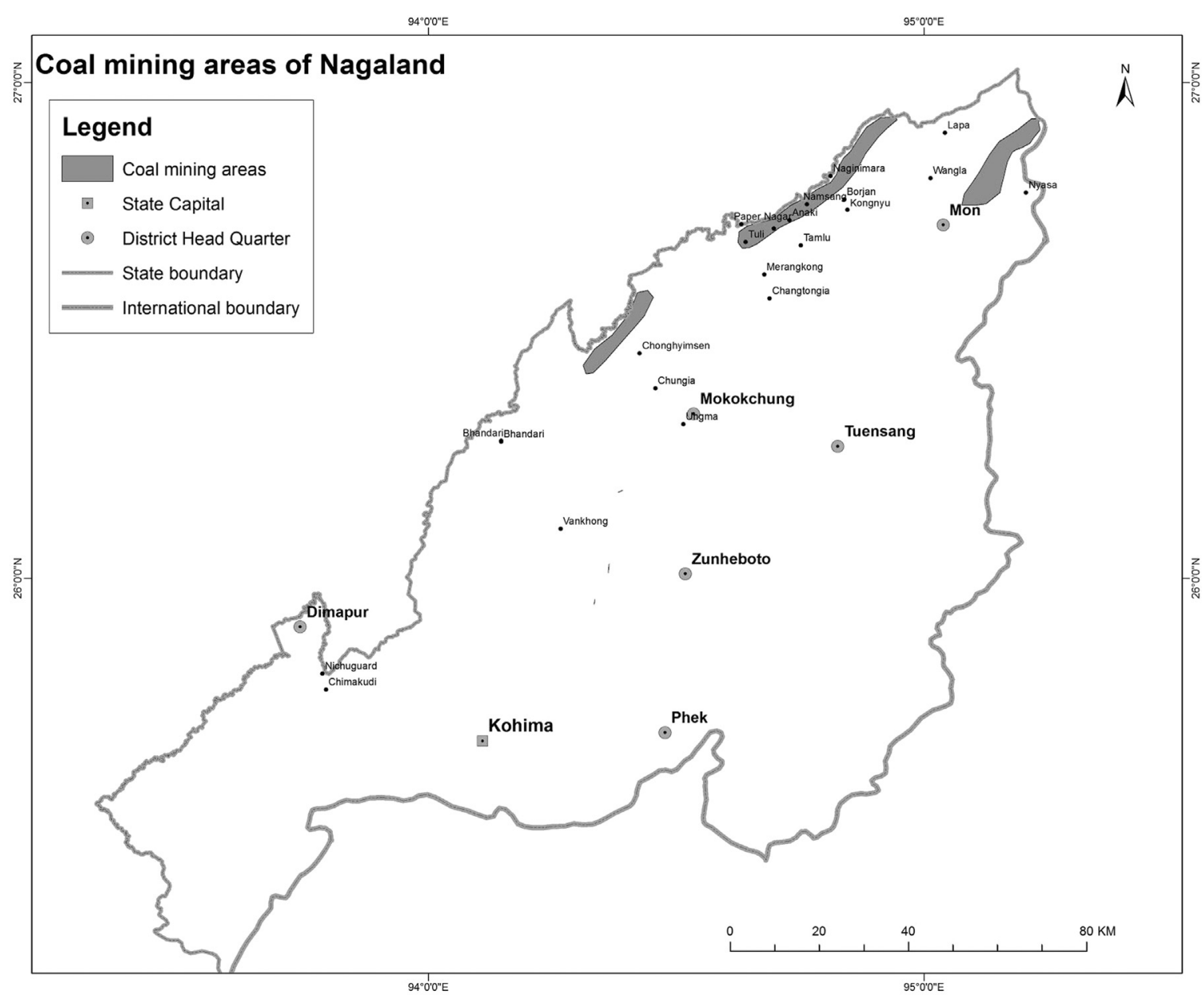

Map 2.0. Coal mining areas of Nagaland. Courtesy Sarat Phukon. Used with permission.

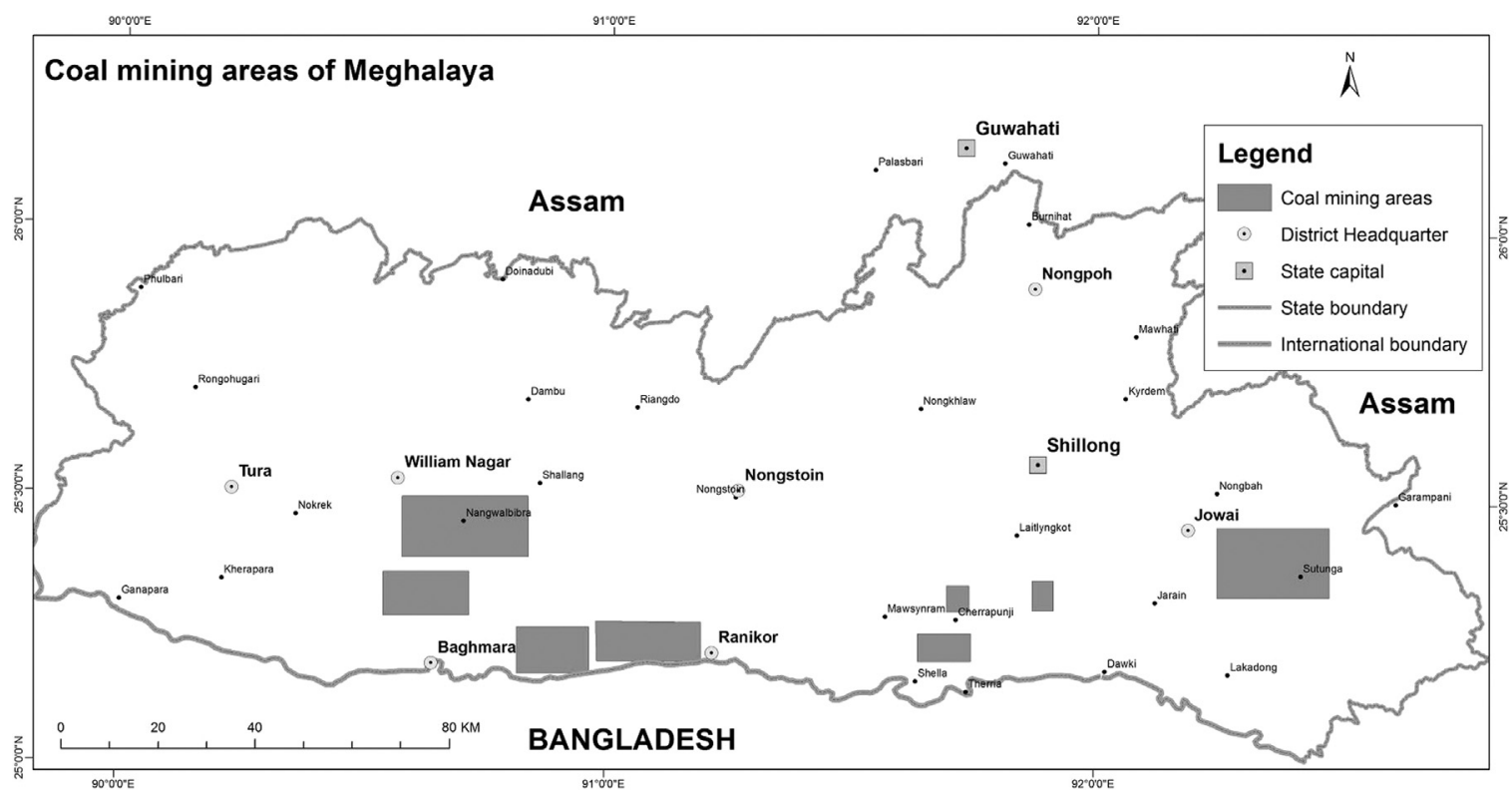

Map 3.0. Coal mining areas of Meghalaya. Courtesy Sarat Phukon. Used with permission.

extractive resource activities and its impact on communities in Northeast India was funded by the Wenner-Gren Foundation Dissertation Fieldwork Grant GR 8031, Wenner-Gren Engaged Anthropology Grant AG-87, and the Riksbankens Jubileumsfond Postdoctoral Fellowship P12-1342:1

\section{References}

Anik, S.S.B., 2015. Indian Court Lifts Ban on Coal Export Till Nov. Dhaka Tribune, August 5.

Bakshi, P.M., 2014. Commentary on the Constitution of India. Universal Law Publications, New Delhi. 
Ballard, C., Banks, G., 2003. Resource wars: the anthropology of mining. Annu. Rev. Anthropol., 287-313.

Barbora, S., 2008. Autonomous districts and/or ethnic homelands: an ethnographic account of the genesis of political violence in Assam (North-East India) agains the normative frame of the Indian constitution. Int. J. Minor. Group Rights 15 313-334.

Baruah, S., 2005. Durable Disorder: Understanding the Politics of Northeast India. Oxford University Press, New Delhi.

Baruah, S., 2001. Clash of resource use regimes in Colonial Assam: a nineteenthcentury puzzle revisited. J. Peasant Stud. 28, 109-124.

Baviskar, A., 1997. Tribal politics and discourses of environmentalism. Contrib. Indian Sociol. 31, 195-223.

Bedi, H.P., Tillin, L., 2015. Inter-state competition, land conflicts and resistance in India. Oxf. Dev. Stud. 43, 194-211.

Brown, I., 2009. British firms and the end of empire in Burma. Asian Aff. 40, 15-33.

Burton, B., 2016. Is India Starting to Waver on Coal? End Coal. February 3.

Census of India, 2013. Census Info India., 2013.

Dove, M.R., 2006. Indigenous people and environmental politics. Annu. Rev. Anthropol. 35, 191.

Eastern Mirror, 2014. Konyak Union Revokes Ban on Coal Extraction in Mon. Eastern Mirror.

Ghosh, K., 2006. Between global flows and local dams: indigenousness, locality, and the transnational sphere in Jharkhand, India. Cult. Anthropol. 21, 501-534.

Government of Meghalaya, 2012. The Meghalaya Transfer of Land (Regulation) Amendment Act, 2010. Gazette of Meghalaya, (No.LL)(B) 190/82/104.

Government of Meghalaya, 1971. The Meghalaya Transfer of Land (Regulation) Act, 1971. The Gazette of Meghalaya, No.MREV.285/Bill/70/142.

Government of Meghalaya. Minerals of Meghalaya, 2015

Government of Nagaland, 2014a. Nagaland Coal Policy (1st Amendment) Rules.

Government of Nagaland, 2014b. Nagaland Coal Policy (1st Amendment).

Government of Nagaland, 2009. Investment Opportunities in Mineral Sector in Nagaland. Directorate of Geology and Mining, Dimapur, Nagaland.

Haokip, T., 2014. Inter-ethnic relations in Meghalaya. Asian Ethn. 15, 302-316.

Iqbal, I., 2015. The space between nation and empire: the making and unmaking of eastern Bengal and Assam Province, 1905-1911. J. Asian Stud. 74, 69-84.

Islam, S., 2014. Govt Moves to Halve Coal Duty on Import, India Bans Export to Bangladesh. Financial Express (Dhaka), 22.

Kar, B., 2009. When was the Postcolonial? A history of policing impossible lines. In: Baruah, S. (Ed.), Beyond Counterinsurgency: Breaking the Impasse in Northeast India. Oxford University Press, New Delhi, pp. 49-77.

Karlsson, B.G., 2011. Unruly Hills: a Political Ecology of India's Northeast. Berghahn Books, New York.

Kennedy, J., King, L., 2013. Adivasis, maoists and insurgency in the central Indian Tribal Belt. Eur. J. Sociol. 54, 1-32.

Khan, S, 2014. Black gold across the Simsang. Tehelka 45.

Kikon, D., 2014. Disturbed Area Acts: Intimacy, Anxiety and the State in Northeas India (Ph.D. thesis). Stanford University, Palo Alto, California.

Kikon, D., 2010. Mining the Militarization: Coal Tales from Northeast India. Times of India, Mumbai.

Kirsch, S., 2014. Mining Capitalism: The Relationship Between Corporations and Their critics. University Of California Press, Berkeley, California.

Li, T.M., 2002. Engaging simplifications: community-based resource management, market processes and state agendas in upland Southeast Asia. World Dev. 30 265-283.

Li, T.M., 2000. Articulating indigenous identity in Indonesia: resource politics and the tribal slot. Comp. Stud. Soc. Hist. 42, 149-179.

Liu, A.B., 2010. The birth of a noble tea country: on the geography of colonial capital and the origins of Indian tea. J. Hist. Sociol. 23, 73-100.

Ludden, D., 2012. Spatial inequity and national territory: remapping 1905 in Bengal and Assam. Mod. Asian Stud. 46, 483-525.

Madhavan, P., 2005. Ant people. East. Panor. 14, 8-10.

Mathur, P.R.G., 1982. Khasi solidarity movement. In: Singh, K.S. (Ed.), Tribal Movements in India. Manohar, New Delhi, pp. 181-202.

May, A.J., 2014. Homo in nubibus: altitude, colonisation and political order in the Khasi Hills of Northeast India. J. Imp. Commonw. Hist. 42, 41-60.

McDuie-Ra, D., 2016. Borderland City in New India: Frontier to Gateway. Amsterdam University Press, Amsterdam.

McDuie-Ra, D., 2014. The India-Bangladesh border fence: narratives and political possibilities. J. Borderl. Stud. 29, 81-94.
McDuie-Ra, D., 2009. Vision 2020 or re-vision 1958: the contradictory politics of counter-insurgency in India's regional engagement. Contemp. South Asia 17, 313-330.

McDuie-Ra, D., 2007. Anti-development or identity crisis? Misreading civil society in Meghalaya, India. Asian Ethn. 8, 43-59.

Miklian, J., Carney, S., 2013. Corruption, justice and violence in democratic India. SAIS Rev. Int. Aff. 33, 37-49.

Miller, M.T., 2015. The Horrors of Rat Hole Mining. Woodrow Wilson Center/Think Out Loud Productions. Documentary Film.

The Meghalaya Mines And Minerals Policy, 2012. Gazette of Meghalaya, 96.

Ministry of Law and Justice (India), 2015. The coal mines (Special Provisions) Act, 2015. Gaz. India 11.

MODONER Ministry of Development North East Region, 2008. North East Vision 2020. Volume 1.

Morung Express, 2011. With Article 371, State Can Decide on Land Resources. Morung Express.

Nongbri, T., 1999. Forest policy in North-East India. Indian Anthropol. 29, 1-36.

North Eastern Social Research Centre NESRC, 2013. Welfare of Children in Coal Mining Areas of Meghalaya. North Eastern Social Research Centre, Guwahati.

Office of the Chief Economist Australia, 2015. Coal in India 2015. Department Of Industry And Science, Canberra.

Oil and Natural Gas Commission ONGC, 2009. Assam and ONGC: Synergy of Over 50 Years. Deputy General Manager, Corporate Communications ONGC, Nazira.

Oskarsson, P., 2013. Dispossession by confusion from mineral-rich lands in Central India. South Asia: J. South Asian Stud. 36, 199-212.

Padel, F., Das, S., 2010. Cultural genocide and the rhetoric of sustainable mining in east India. Contemp. South Asia 18, 333-341.

Ribot, J.C., Peluso, N.L., 2003. A theory of access. Rural Sociol. 68, 153-181.

Routledge, P., 2003. Voices of the dammed: discursive resistance amidst erasure in the Narmada Valley, India. Political Geogr. 22, 243-270.

Ruparelia, S., 2015. 'Minimum government, maximum governance': the restructuring of power in Modi's India. South Asia: J. South Asian Stud. 38, 755-775.

Saikia, A., 2011. Imperialism, geology and petroleum: history of oil in colonial Assam. Econ. Political Wkly. 46, 49-55.

Saikia, A., 2008. Forest land and peasant struggles in Assam, 2002-2007. J. Peasant Stud. 35, 39-59.

Saikia, A., 2005. Jungles, Reserves, and Wildlife: a History of Forests in Assam, Wildlife Areas. Development And Welfare Trust, Guwahati.

Saikia, A., 2014. Coal in colonial Assam: exploration, trade, and environmental consequences. In: Lahiri-Dutt, K. (Ed.), The Coal Nation: Histories, Ecologies, and Politics of Coal in India. Ashgate, Farnham UK/Burlington US, pp. 63-78.

Sharma, J., 2009. 'Lazy' natives, coolie labour, and the Assam tea industry. Mod. Asian Stud. 43, 1287-1324.

Sharma, J., 2006. British science, Chinese skill and Assam tea Making empire's garden. Indian Econ. Soc. Hist. Rev, 43, 429-455.

Shillong Times, 2016a. Govt Submits Coal Miners' List to NGT.

Shillong Times, 2016b. Three Arrested for Ngt Ban Violation.

Shillong Times, 2015a. NGT Violations Continue in Meghalaya.

Shillong Times, 2015b. Govt to Start Work on Mining Policy.

Shillong Times, 2014a. Coal Body Calls Indefinite Economic Strike from Sep 23

Shillong Times, 2014b. Nagaland Konyak Union to Ban Coal Mining for Unsafe Method.

Siddiqi, F.A., 2015. Curse of the Black Gold: How Meghalaya Depends on Coal. Hindustan Times.

Swer, S., Singh, O., 2004. Status of water quality in coal mining areas of Meghalaya, India, In: Proceedings of the national seminar on environmental engineering with special emphasis on mining environment, NSEEME-2004, pp. 19-20.

Suykens, B., 2009. The tribal-forest nexus in law and society in India: conflicting narratives. Crit. Asian Stud. 41, 381-402.

The Hindu, 2013. Migrant Workers Fleeing Meghalaya After 8 Killed.

Vakkayil, J., Canato, A., 2015. Muddling through: searching for the ideal in the coal mining fields of Meghalaya. Extr. Ind. Soc. 2, 419-425.

Vandergeest, P., 2003. Racialization and citizenship in Thai forest politics. Soc. Nat. Resour. 16, 19-37.

Wagle, D., 2010. Dhkar still. Himal Southasian 23, 45-46. 